\title{
A ROYAL STONE DECREE (DATED 948H.) IN KALYAN MOSQUE OF BUKHARA
}

Islamic dept. Faculty of Archaeology, Cairo University, Egypt - e-mail: sheblebaid@hotmail.com

\begin{abstract}
Bukhara is rich in many of the architectural buildings that dated back to different historical periods, in addition they are decorated with a wide range of different inscriptions, Applied on inscriptions include many documentary texts. It is remarkable that these texts include "A royal decree" executed in the stone, on the south side of the portal-pishtaq -of Kalyan Mosque. This decree is one of the rarest examples of royal decrees found inscribed on the buildings in Central Asia, in general, and in architecture of Bukhara, in particular, especially as most of the decrees known from region of the kind called "yarliqs" mostly kept now in the archives of Central Asia.
\end{abstract}

Keywords: Royal stone decree, Kalyan Mosque, Bukhara, Nasta'liq script

\section{Introduction}

Bukhara $^{(a)}$ is rich in many of the architectural buildings that belong to different historical periods, contain numerous inscriptions on many of architectural elements. The contents of these inscriptions were including both religious and secular them were a number of construction inscriptions, which contained titles, names of khans and dates of completion. It is remarkable that these Inssscccriptions that include "Royal Decree" executed in the stone, on South side of the main portal- pishtaq- of Kalyan Mosque $^{(b)}$, fig. (1)

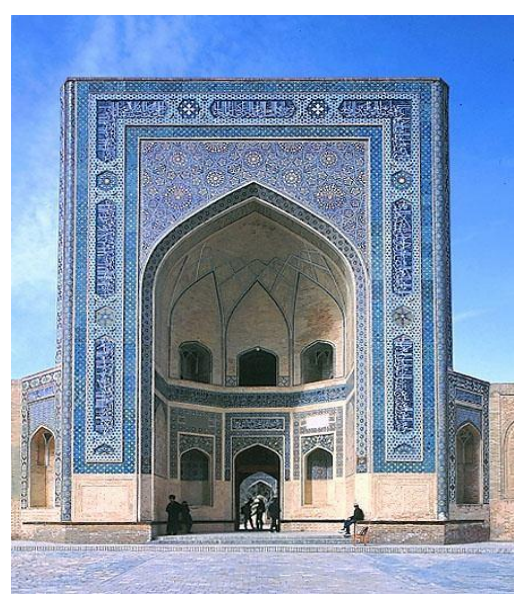

Figure (1) فhe portal of Kalyan Mosque 


\section{Objectives of the study}

It is one of the rarest examples of royal decrees inscribed on the buildings in Central Asia in general and in architectural building of Bukhara, especially as most of the decrees known from that region are of the kind called" yarliqs" which are mostly kept now in the archives of central Asian [1]. This decree is executed in Nasta'liq script, which indicates that Persian language was the language of the prevailing culture during tenth century $\mathrm{H}$.

\section{Decree text}

A royal stone decree dated $948 \mathrm{H}$. in Kalyan mosque of Bukhara consists

of five horizontal lines as shown in fig. $2(a, b)$

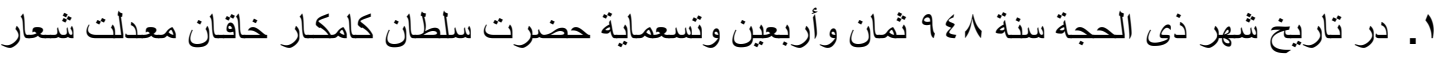

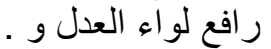

$$
\begin{aligned}
& \text { r. الأمان قامع أبنية الجور و العدوان صاحب الجود و الكرم والنذور أبو الغازى سلطان عبد العزيز بهادر خلد } \\
& \text { الله. } \\
& \text { r. ملكه ودولته بخشيدند بر عاياى بلده فاخرة بخار البلغ سى وشش هزار بيكجه نقلى وهشده هزار وسيلة }
\end{aligned}
$$

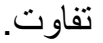

$$
\begin{aligned}
& \text { ع. بقجه عرضى كـ را وبيست و هفت هزار تنكجه توفرى ر اكه مجموع هشتاد ويك هزار تنكه ميشود وفر مودند }
\end{aligned}
$$

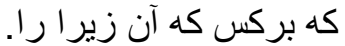

$$
\begin{aligned}
& \text { •. تبديل با بتار اج از مردم بستاند در لغت خداى لعنت خداى تعالى وفركشتكان وبيغبر ان وسـاير خاكيان }
\end{aligned}
$$

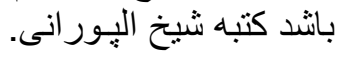
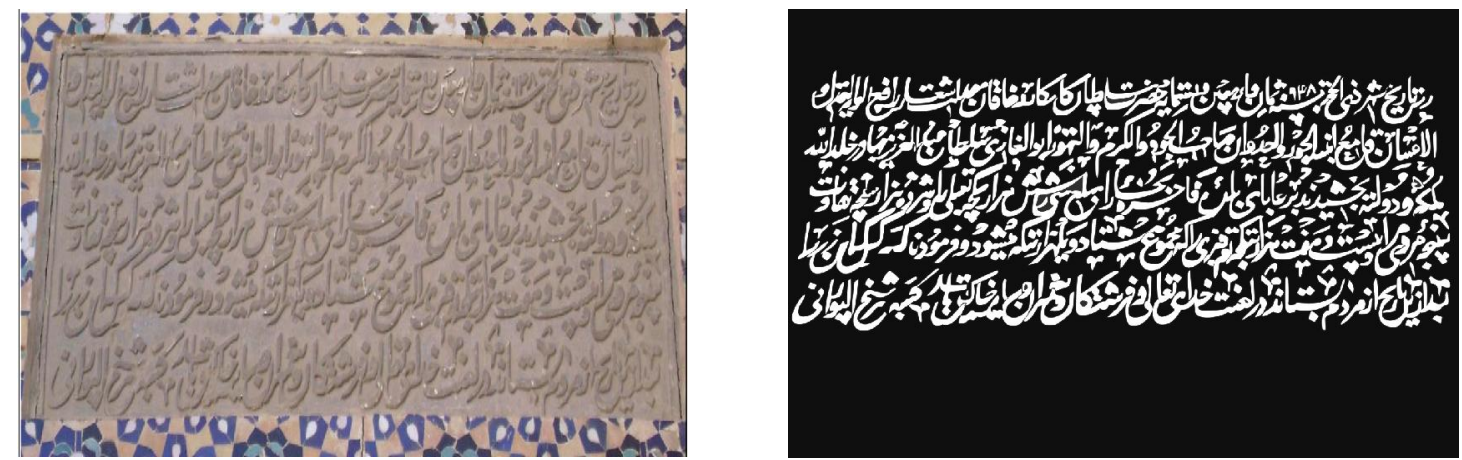

Figure $2(\mathrm{a}, \mathrm{b})$ a royal stone decree on the south side of the main portal of kalyan mosque and its text.

\subsection{Translation of these five lines}

$1^{\text {st }}$ line: On the date of the month of Dhul-Hijjah 948 nine hundred and forty eight, the victorious Sultan, symbol of justice khaqan standard bearer of the banner of justice and. $2^{\text {nd }}$ line: Safety, vanquisher of the buildings of injustice and aggression, owner of generosity, kindness and vows, Abū'l-Ghāzī Sultān 'Abd al-'Aziz Bahādur , may God perpetual. $3^{\text {rd }}$ line: His kingdom and his state, proprietor of generosity and

\subsection{Comment about the decree}

Decrees were put in public places to inform the people about their contents, so they were carved in stone in prominent places, such as mosques, schools, bemmarstan, and on the gates kindness gave the subjects of the city of Bukhara al- Fakhira, amount of thirty six thousand Tanga Naklī and eighteen thousand. $4^{\text {th }}$ line: Bakjha and twentyseven thousand Tanga tawaffurī, thus, a total of eighty-one thousand Tanga. $5^{\text {th }}$ line: He prayed that who replaces or seizes it by stealing from the people may the curse of God, his Angels, Prophets and all people be upon him, written by Shaykh al-pūrānī .

and walls of cities [2]. This decree executed in Nasta'liq script, has a great importance because of its uniqueness, as it is the only example found in that the architectural buildings of Bukhara. 
It has a release date stating the month of Dhul -Hijjah 948 H., recorded in numbers and letters, in the first line of the decree, which includes a Grant awarded by the Sultan of Bukhara, which is described in the decree "luxurious Bukhara "Bukhara alFakhira" $^{(\mathrm{C})}$. As for the one who issued the decree; it was Sultan, "Abd al'Aziz Bahādur b. 'Obayd allāh Khān (948- 958H. / 1541 - 1551), "who issued the decree the same year in which he reigned the throne and perhaps the reason for its release was to gain the favor of the population of Bukhara in that edgy period. It is noteworthy that the title of "Sultan" was mentioned twice in the inscription, in lines I and II, he took the title" Hāqān, or Khān"after the death of his father and his assumption of the rule of the city of Bukhara. But he was not given the title officially since he was not the elder son and because he entered into a conflict with the governor of Samarkand, "Abd-al-Lațîf Solțān ben Kučkuṇči" and the Governor of Tashkent "(Nawrūz Ahmad Khan [Baraq Khan]", who later became high Khan of the Uzbek after "Abd-alLatāf" during of 959 -963 H. / 15521556 [3]. With regard to the titles, which accompanied the name of Sultān 'Abd al-'Aziz Bahādur Khān, the " symbol of justice khaqan standard bearer of the banner of justice and Safety, vanquisher of the buildings of injustice and aggression, owner of generosity, kindness and vows" , they reflect the policy which will be followed by the new Sultan stressing his commitment to standard bearer of the banner of justice in his rule and to achieve safety for the subjects of the city of Bukhara, in addition the Sultan was described as a vanquisher of the buildings of injustice and aggression, as well as his desire to get closer to his subjects through granting money and gifts as mentioned in this decree. What further stresses the character of 'Abd al-'Aziz Bahādur is what was mentioned by "Vambry" that:" "Abd al"Aziz fostered the influence of the mullah in reviving a strict religious tone, and expended far more care on building Mosques and convents, and on other pious works than on secular objects [4]. Concerning the subject of the decree it deals with the grant donated by the sultan to the people of Bukhara, which comprises an amount of the thirty-six thousand Tanga ${ }^{(\mathrm{d})}$. In addition to twenty-seven Tanga Tawaffuri $^{(\mathrm{e})}$, and eighteen thousand Bundles of fabric ${ }^{(\mathrm{f})}$, the price of each Bundle being one Tanga, so the grant total of Sultan " 'Abd al-'Aziz " finally reaching a total of eighty-one thousand Tanga. Through the analysis of that grant, which was awarded by" "Abd al"Aziz Bahādur" to the subjects of the city of Bukhara, we find that it included eighteen thousand Bundles of fabric, we assume that every Bundle would be distributed to one family with an average of five members (father + mother + three children). And then we can calculate a population of Bukhara in that period, of approximately $(5 \times 18$ =90) (about ninety thousand persons). Regarding the cash which was distributed to residents of Bukhara, together with every bundle of cloth, its amount was as follows (36 thousand Tanga +27 thousand Tanga Tawaffuri $=63$ thousand Tanga). When the total of this money is divided by the total number of bundles of cloth, we will get the amount of cash which was distributed with each bundle of cloth to the population of Bukhara from the total donation, which was awarded to them, which is three and a half Tanga distributed to each family. Thus, the actual value of the gift that has been distributed, both as a gift of cash and of the material equal four and a half Tanga for each family in the city. 


\subsection{The carver's name}

The carver's name of the Decree is Mir-sheikh-al-purani ${ }^{(\mathrm{f})}$, who signed his name under the mentioned Decree of 'Abd al-'Aziz Bahādur. The same name of the master Bayazid purani is inscribed on the mosaic band of the mihrab of the Kalyan mosque, fig. (3). Thus this is the same name. And we can conclude that the mihrab was built in 948H./ 1541.

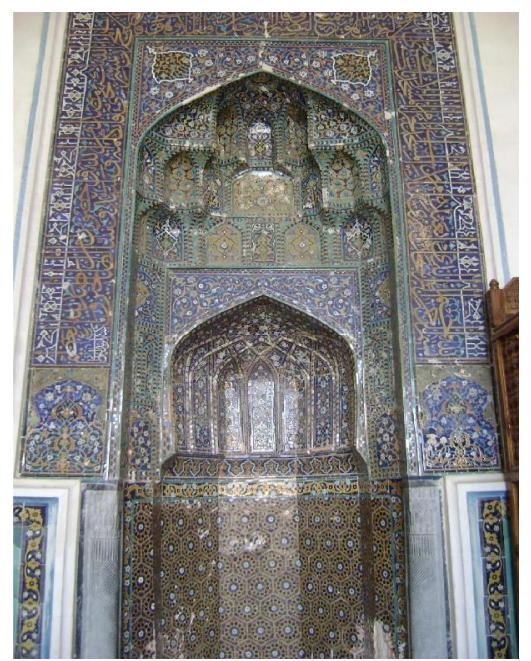

Figure (3) the carver's name on a mosaic band of the mihrab.

\section{Conclusion}

This decree is one of the rarest examples of royal decrees inscribed on the buildings in Central Asia in general and in architectural building of Bukhara, in particular, on the other hand, the known kind of these decrees which called "yariiqs" mostly kept now in archives of Central Asia. - Concerning the subject of the decree it deals with the grant donated by the sultan to the people of Bukhara, which included money and bundles of fabric. - This decree also includes the name of the calligrapher is Mir-sheikh-al-purani. This name of the master purani is also inscribed on the mosaic band of the mihrab of the same mosque.

\section{Endnotes}

(a) Abu'l-Hasan Nishapuri in the book "The Treasury of the sciences" has contended that the city of Bukhara, although the Oxus river is in the Middle of it. Ahmad ibn Muhammad ibn Nasr says that Bukhara has many Names. In his book he calls it "Numijkat" in another place I saw "Bumiskat" in another place it is written in Arabic madinat al-sufriya- the copper cityand another place, also in Arabic "madinat al-tujjar" the city of merchants, see, AlNarshakhi, The history of Bukhara, Translated to English, R. N.,Frye,( 2007), PP. 15,27.

(b) Although the history of Bukhara seems to go back to the $1^{\text {st }}$ century B.C.E., the framework of the existing city was established after the Islamization in the $8^{\text {th }}$ century. It was in 794 that the Friday Mosque, in which whole inhabitants of the city could congregate for worship, was eventually erected in the present precinct after several times of renovations, having started as a wooden structure. It is referred to as 'Kalyan Mosque' in Tajik, which means 'Great Mosque.' Though it was thoroughly reconstructed in 1127, Genghis Khan destroyed it 100 years later. For whatever reason, only its Minaret has escaped from the demolition, showing its archaic but graceful brick figure still now. - P., Chuvin, Samarkand, Bukhara, Khiva, Paris 2003, p117.

(c) There has come down in one tradition the Name Fakhira for Bukhara, because on the Judgment Day Bukhara shall excel all other cities in glory because of the multitude of martyrs (buried there), see, Al-Narshakhi, The history of Bukhara, pp.27-28.

(d) Tanga: Islamic coinages are traditionally pronounced tanga or tenge in persian and Turkish speaking lands and tanka in Indian sub-continet. The earliest appearance of the word occurs in a coin legend on the bilingual Arabic/Sanskrit silver issued by the Ghazanawid ruler Mahmūd b. sebüktigin in 
Mahmüdpür (Lahawr) in 418 H./1027-8. In the west where the word was pronounced tanga or tenge, the name was given to the reform cilver coinage introduced by Timūr in $796 \mathrm{H} . / 1394$. The tanga continued to be the generic name for the principal silver denominations issued by the Karā Koyunlu, Aks koyunlu, Shaybānids and many minor Persian and central Asia, see - M.Z., Kirmani, Encyclopaedia of Islamic science and scientists, Vol. I, First Edition (New Delhi, 2005), pp.190-191.

\section{References}

[1] Levi, C., ( 2010). Islamic Central Asia an Anthology of Historical Sources, Indian University Press.

[2] Othman, A., (1983). Al-mrasem alhajarya mn wasael al-e'alam fi al-asr al-mamluke, Journal of the faculty of Arts, Assiut University-Sohag branch,Vol., 3, pp:157- 168 (e) Tanga Tawaffuri : I don't have information about it.

(f) Bundles of fabric, see, A.A.Dehkhoda, Loghatnameh Dehkhoda,Tehran University, B- letter,( Tehran, 1345).

(g) Puran: A wide kingdom of Ghazni in Zbilstan province, see, M., Shaykh alRabwah, Nukbat Ad dahr fi 'Adsohā'ib al barr wal bahr, Mehren, A., (Leipzig, 1998, p. 181).

[3] Caakov, B., (1996), Hctorua Bukhara: 100 vabrocov e otvetov, Shark, Tashkent.

[4] Vambery, A., (1873). History of Bukhara from the Earliest period down to the present, London 